\title{
Isolated tubal torsion after tubal ligation and ectopic pregnancy: A case report
}

\author{
Ektopik gebelik ve tüp ligasyonu sonrast izole tubal torsiyon: Olgu sunumu \\ İbrahim Alanbay*, Hakan Çoksuer, Cihangir Mutlu Ercan, Kazım Emre \\ Karaşahin, Uğur Keskin, Mehmet Sakıncı, Hüseyin Pehlivan, İskender Başer
}

Department of Obstetrics and Gynecology (Asst. Prof. İ. Alanbay, MD., Asst. Prof. H. Çoksuer, MD., Asst. Prof. C. M. Ercan, MD., Asst. Prof. K. E. Karaşahin, MD., Asst. Prof. U. Keskin, MD., Asst. Prof. M. Sakınc1, MD., H. Pehlivan, MD., Prof. İskender Baser, MD.) Gulhane Military Medical Academy, TR-06018 Ankara

\begin{abstract}
This case report focused on a 40-years-old female patient who had right isolated tubal torsion presented with acute pelvic pain. A 40-years-old woman was admitted to hospital due to acute pelvic pain without nausea and vomiting. Ultrasound examination revealed a well circumscribed right adnexal cystic mass, without septations, measuring $71 * 60 \mathrm{~mm}$. Laparoscopy had revealed the torsion of the right hydrosalpinx and right salpingectomy was performed afterwards. The patient had a history of 5 ectopic pregnancy, 2 laparoscopic salpingostomy and 1 laparoscopic tubal ligation previously. Isolated tubal torsion is a rare but should be kept in mind a possible pathology in differential diagnosis of current lower abdominal pain. Laparoscopy could be useful in diagnosing and treating the cases with isolated tubal torsion.
\end{abstract}

Keywords: Isolated tubal torsion, tubal ligation, ectopic pregnancy, laparoscopy

\section{Özet}

$\mathrm{Bu}$ olgu sunumu akut pelvik ağrı ile başvuran, izole sağ tuba torsiyonu olan 40 yaşındaki kadın hastayı sunmaktadır. 40 yaşındaki kadın, bulantı ve kusma olmaksızın akut pelvik ağrı şikâyeti ile hastaneye kabul edildi. Ultrason muayenesi ile 71*60 mm ölçülerindeki, septasyonun olmadığ sınırlı sağ adneksiyal kistik kitle saptandı. Laparoskopi ile să̆ hidrosalpenks torsiyonu gösterilmiştir ve daha sonrasında sağ salpingektomi yapılmıştır. Hastanın öyküsünde 5 kez ektopik gebelik, 2 defa laparoskopik salpingostomi ve $1 \mathrm{kez}$ de laparoskopik tüp ligasyonu mevcuttur. İzole tuba torsiyonu nadir görülür ancak mevcut alt karın ağrısının ayırıcı tanısında akılda tutulması gereken mümkün bir patolojidir. Laparoskopi, izole tuba torsiyonu olan olguların teşhis ve tedavisinde faydalı olabilir.

Anahtar sözcükler: İzole tubal torsiyon, tüp ligasyonu, ektopik gebelik, laparoskopi

Geliş tarihi/Received: May 02, 2011; Kabul tarihi/Accepted: August 05, 2013

\section{*Corresponding address:}

Dr. İbrahim Alanbay, Kadın hastalıkları ve Anabilim Dalı, Gülhane Askeri Tıp Akademisi, TR06018, Ankara, E-mail: ialanbay@gmail.com

\section{Introduction}

Isolated tubal torsion is one of the rare causes of lower abdominal pain [1, 2]. It's incidence in women at reproductive age is reported as 1/500.000/woman [3]. Absence of pathognomonical symptoms, presence of nonspesific findings at physical examination and absence of ultrasound and laboratory findings are the facts resulting difficulties for 
early diagnosis of these cases. Diagnosis is usually made intraoperatively. It's commonly diagnosed on the single side and more often on the right tubal area in periovulatory period of the women at reproductive age, however, it's also reported in premenarche, adolescent, menopause and post-menopausal periods [4]. Although different predisposing factors were detected in etiopathogenesis, the cause of spontaneous (idiopathic) ITT (Isolated Tubal Torsion) is not known precisely. Since possible loss of fertility is a common result of delay in diagnosis of ITT in the reproductive age, clinical suspicion and early intervention has significant importance. In this case report a case admitted to our clinic with right groin pain and diagnosed with ITT intraoperatively is being discussed.

\section{Case report}

A 40 years old patient was admitted to our clinic with cramping right lower quadrant pain, without nausea and vomiting. The patient's gravidity was 6 , with only one vaginal delivery, the other 5 pregnancies being ectopic. She had been given Methotrexate 3 times and 2 laparoscopic interventions for ectopic pregnancies. She also had another laparoscopy for tubal sterilization.

In physical examination, generalized abdominal tenderness has been identified which was prominent in the right lower quadrant. Guarding and rebound were also present. In vaginal examination cervix movements were painless. In transvaginal ultrasonographic evaluation uterine size was normal, endometrial echo was regular, left ovary was in normal size, in the right adnexial lodge a cystic mass of homogeneous nature measuring approximately $71 \mathrm{~mm} * 60 \mathrm{~mm}$ had been viewed (figure 1a). No free fluid was observed in Douglas pouch. In laboratory tests $\beta$ HCG was negative, Hemoglobin: $14.5 \mathrm{~g} / \mathrm{dl}$, leukocyte count: 7600 and routine blood biochemistry results were normal.

We decided diagnostic laparoscopy for the patient with preliminary diagnosis of right adnexial mass. The uterus and both of ovaries observed and had been viewed as normal during intra-abdominal laparoscopic exploration. Bilateral tubes found ligated and previous tubal ligation sites were identified (figure 1b). Right tube had been viewed as torsioned 4 times around itself (figure 1c). Right hydrosalpinx had been viewed (figure 1d). Tube had been detorsioned and salpingectomy performed subsequently. The patient was discharged on the second day post-operatively without any complication.

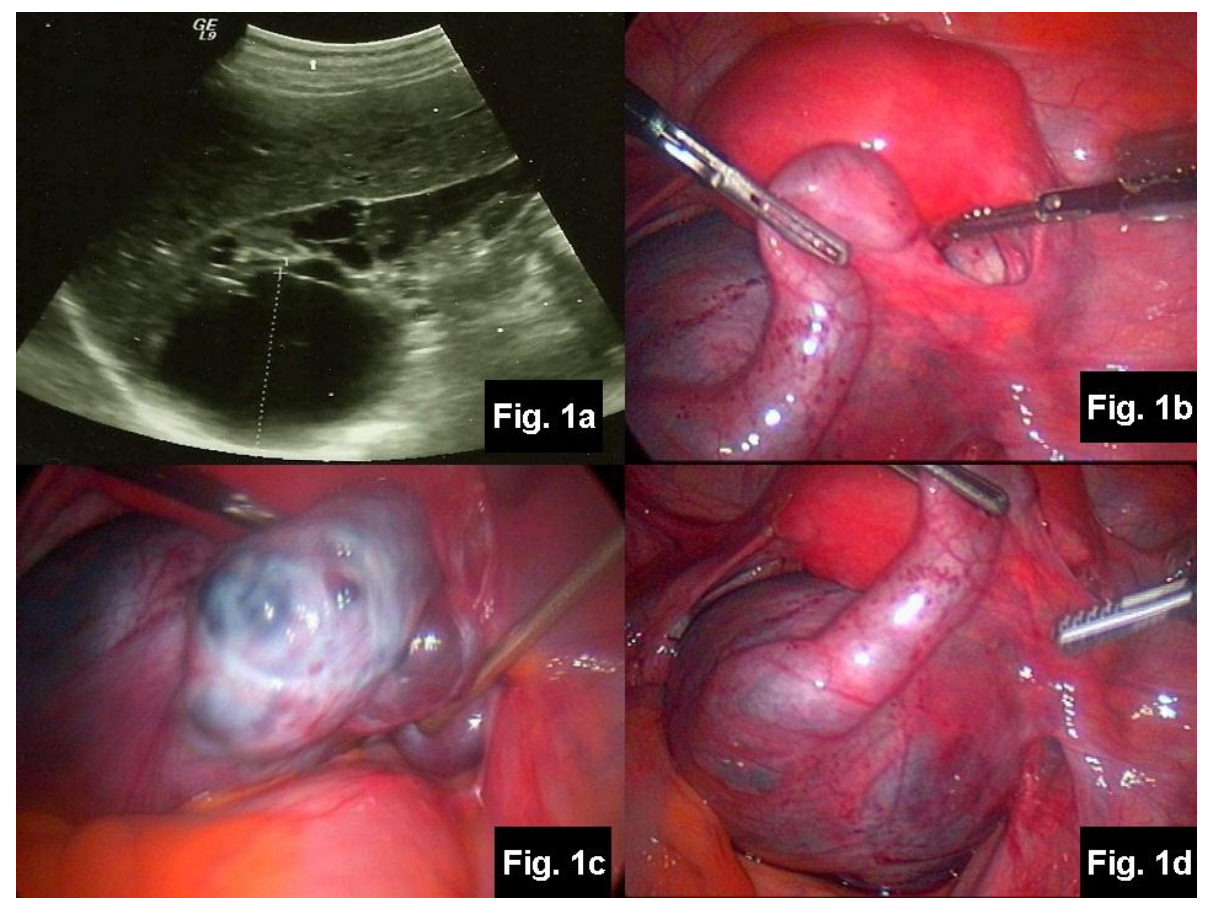

Figure 1a, b, c, d: The ultrasonographic and intaoperative view of right torsioned hydrosalpinx. 


\section{Discussion}

Isolated tubal tortion is one of the rare causes of lower abdominal pain. Mostly seen in women at reproductive age, the overall incidence is reported as 1/500.000/woman [1-3]. In publications in which isolated tubal torsion had been reported, they were most frequently viewed on the right side. Among the reasons why the right sided pathology predominates, the protective role of sigmoid colon has been mentioned, which situated in the left lower quadrant, via its mass effect on the left tube could keep it from turning around its pedicle, as well as the operative approach of surgeons to the patients admitted with right lower quadrant pain due to suspicion of acute appendicitis. There are also opinions proposing that the difference between the venous circulatory systems of the right and left tubes increases the incidence on the right side [5-6]. Although the mechanism of ITT remains unknown precisely, a variety of theories has been put forward. These theories are divided into two as intrinsic and extrinsic [7]. Intrinsic reasons are; congenital anomalies, hydrosalpinx, haematosalpinx, tubal neoplasms, autonomic dysfunction, abnormal peristaltism, primary tubal surgery such as tubal ligation. Extrinsic reasons are ovarian and paratubal masses, pregnancies, trauma, adhesion and pelvic congestion [8]. A study showed that increased risk of subsequent hydrosalpinx formation in women with a history of tubal ligation, compared with those who had no history of tubal ligation [9].

In this case, our patient underwent 3 times tubal surgery 2 for ectopic pregnancies and 1 for tubal ligation and this was thought to be a predisposing factor for tubal torsion.

Like in our case, in the literature there are 9 reported cases of hydrosalpinx and tubal torsion developed after bilateral tubal sterilization [10]. The most frequent symptom of ITT is nonspecific acute lower quadrant pain. The pain is usually not accompanied by nausea and vomiting, and may be cramping or intermittent. In physical examination abdominal tenderness is determined, specific mass may not always be palpated [11]. Laboratorial values are usually within normal ranges. Ultrasonography (USG) is diagnostic gold standard for suspected adnexal tortion. Typically USG should reveal a cystic adnexial mass with hyperechoic walls tapered towards the uterine corn and the ipsilateral ovary should be viewed intact [12]. Doppler USG can be useful in terms of showing the viability of ipsilateral ovary; but normal vasculature of the ovary cannot exclude ITT [13]. Absence of specific symptoms and physical exam findings as well as absence of specific laboratuary and USG findings cause difficulties in early diagnosis. ITT should be taken into consideration besides acute appendicitis, ectopic pregnancy, PID, ovarian tortion, rupture of ovarian cyst, intestinal obstruction or perforation, ürolithiasis, cystitis and degeneration of leiyomyoma in the differential diagnosis of the patients who present with acute lower quadrant pain and results of clinical, laboratory, physical examination that are non-specific [14].

It's extremely important to consider. ITT in the forefront for early detection and intervention in patients admitted with acute lower abdominal pain and adnexial mass on ultrasound with normal appearence of both ovaries, especially in terms of continuity of fertility.

But unfortunately, studies often showed that the preoperative diagnosis is difficult and the diagnosis can usually be made intraoperatively. Primary methods used in the treatment of ITT are explorative laparotomy or laparoscopic surgery. If there is no contraindication, laparoscopy is the first preferable approach for diagnosis or treatment. The risk of postoperative pelvic adhesions is also less in laparoscopy than laparotomy. In the case of pregnant women may develope an ITT, laparoscopy is superior to laparotomy in terms of maintenence of healthy pregnancy. Choice of treatment is detorsion or salpingectomy regarding to the appearance of fallopian tube, patient's age and fertility status during the operation [15]. 
If there is no tubal ischemic damage or necrotic appearance those patients benefit from detorsion. We preferred salpingectomy in our case since hydrosalpinx was present in the torsioned tube and she had previous tubal surgeries. Acute pelvic pain in women should be evaluated carefully. Especially in young patients consideration of ITT in the differential diagnoses is important for early intervention in terms of protection of fertility.

\section{References}

1. Ait Benkaddour Y, Bennani R, Aboulfalah A, Abbassi H. Uncommon cause of acute pelvic pain: isolated torsion of hydrosalpinx. Afr J Reprod Health 2009; 13: 147-50.

2. Phillips K, Fino ME, Kump L, Berkeley A. Chronic isolated fallopian tube torsion. Fertil Steril 2009; 92: 394.e1-3.

3. Maor-Sagie E, Zivi E, Ben-Shushan A, Rojansky N. Fallopian tube torsion--a rare complication in the reproductive age. Harefuah 2009; 148: $432-4$.

4. Shukla R. Isolated torsion of the hydrosalpinx: a rare presentation. Br J Radiol 2004; 77: 784-6.

5. Vierhout ME, Wallenburg HC. Torsion of the fallopian tube; a case report of a bilateral non-simultaneous torsion and a review of the literature. Eur J Obstet Gynecol Reprod Biol 1986; 23: 111-5.

6. Warner MA, Fleischer AC, Edell SL, Thieme GA, Bundy AL, Kurtz AB, James AE Jr. Uterine adnexal torsion: sonographic findings. Radiology 1985; 154: 7735 .

7. Youssef AF, Fayad MM, Shafeek MA. Torsion of the fallopian tube. A clinicopathological study. Acta Obstet Gynecol Scand 1962; 41: 292-309.

8. Elchalal U, Caspi B, Schachter M, Borenstein R. Isolated tubal torsion: clinical and ultrasonographic correlation. J Ultrasound Med 1993; 2: 115-7.

9. Morse AN, Schroeder CB, Magrina JF, Webb MJ, Wollan PC, Yawn BP. The risk of hydrosalpinx formation and adnexectomy following tubal ligation and subsequent hysterectomy: A historical cohort study. Am J Obstet Gynecol 2006; 194: 1273-6.

10. Ikeda S, Sumiyoshi M, Oki C. Torsion of the fallopian tube following sterilization. Gynecol Obstet Invest 1998; 46: 271-3.

11. Droegemueller W. Benign gynecologic lesions. In: Comprehensive Gynecology. 3rd ed. Edited by S Baxter. St. Louis, Mosbyyear Book, Inc., 1997; 467-516.

12. Skinner S, Voyvodic F, Scroop R, Sanders T. Isole Tubal Torsion: CT Features. Clinical Radiology 2001; 56: 155-65.

13. Baumgartel PB, Fleischer AC, Cullinan JA, Bluth RF. Color doppler sonography of tubal torsion. Ultrasound Obstet Gynecol 1996; 7: 367-70.

14. Ferrera PC, Kass LE, Verdile VP. Torsion of the fallopian tube. Am J Emerg Med 1995; 13:312-4.

15. Gross M, Blumstein SL, Chow LC. Isolated fallopian tube torsion: a rare twist on a common theme. AJR Am J Roentgenol 2005; 185: 1590-2. 